$\begin{array}{ll}\text { Variants } & \begin{array}{l}\text { Variants } \\ \text { The Journal of the European Society for Textual } \\ \text { Scholarship }\end{array}\end{array}$

15-16 | 2021

Textual Scholarship in the Twenty-First Century

\title{
Walter Benjamin, Berliner Chronik / Berliner Kindheit um neunzehnhundert
}

Jonas Rosenbrück

\section{OpenEdition}

\section{Journals}

Electronic version

URL: https://journals.openedition.org/variants/1514

DOI: 10.4000/variants. 1514

ISSN: 1879-6095

\section{Publisher}

European Society for Textual Scholarship

\section{Printed version}

Date of publication: 1 July 2021

Number of pages: 265-267

ISSN: 1573-3084

\section{Electronic reference}

Jonas Rosenbrück, "Walter Benjamin, Berliner Chronik / Berliner Kindheit um neunzehnhundert", Variants [Online], 15-16 | 2021, Online since 01 July 2021, connection on 16 July 2021. URL: http:// journals.openedition.org/variants/1514 ; DOl: https://doi.org/10.4000/variants.1514 
Review of Walter Benjamin, Berliner Chronik / Berliner Kindheit um neunzehnhundert. 2 vols. Eds. Burkhardt Lindner and Nadine Werner. (Vol. 11(1-2) of Werke und Nachlaß. Kritische Gesamtausgabe. Eds. Christoph Gödde and Henri Lonitz.) Berlin: Suhrkamp Verlag, 2019. 652 and 466 pp. ISBN: 978-3-518-58728-7.

Presented as a "complete critical edition", Walter Benjamin's Werke und Nachlaß [Writings and Literary Estate], published by Suhrkamp since 2008, has opened a new phase in the convoluted reception history of this seminal thinker's work, suggesting that a definitive edition might have finally arrived after decades of belated discoveries of unpublished texts. On behalf of the Hamburger Stiftung zur Förderung von Wissenschaft und Kultur and under the general editorship of Christoph Gödde and Henri Lonitz, as well as in cooperation with the Walter Benjamin Archiv, ten volumes have been published thus far, with eleven still to come. The volume under review here, Berliner Chronik / Berliner Kindheit um neunzehnhundert [A Berlin Chronicle / Berlin Childhood around 1900], published in 2019, gathers an impressive and remarkably useful range of contents: not only all the extant versions of Benjamin's collection of autobiographical vignettes - manuscripts, typescripts, and published versions - but also a lengthy and thorough account of its genesis and publication history - more than a hundred pages of relevant letters, charts establishing meticulous comparisons between texts, and copious annotations. This volume constitutes a crucial test case for the editorial principles of the complete critical edition published by Suhrkamp, for two main reasons: on the one hand, Berlin Childhood occupies a privileged place in the history of German editions of Benjamin's works. It was the first book published in post-war Germany (1950, ed. Theodor W. Adorno) and thus marked the beginning of Benjamin's return to scholarly and public discourse. On the other hand, and more importantly, Berlin Childhood is concerned with two central matters, both of which directly relate to editorial principles and textual scholarship at large: a theory of language (in particular of Schrift [writing]) and a theory of memory and tradition, as it comes to bear on the transmission of texts.

The following passage crystallizes Benjamin's understanding of memory and simultaneously sheds light on the value of the critical edition of Berlin Childhood: 
Wer sich der eignen verschütteten Vergangenheit zu nähern trachtet, muß sich verhalten wie ein Mann, der gräbt. Vor allem darf er sich nicht scheuen, immer wieder auf einen und denselben Sachverhalt zurückzukommen - ihn auszustreuen wie man Erde ausstreut, ihn umzuwühlen, wie man Erdreich umwühlt.

[Whoever desires to approach his own buried past must behave like a man who digs. Above all he must not shy away from returning again and again to the same state of affairs - disseminating it like one disseminates earth, turning it over like one turns over soil.]

Benjamin conceived the work of memory in archaeological terms: a repeated digging up, rummaging through layered memories, and a subsequent dispersal of what has been dug up. The critical edition of Berlin Childhood enables the reader to perform a similar archaeological search, as far as the textual development of Benjamin's collection is concerned: it displays the various layers of the collection's "soil", allowing the reader to rummage through them. The layering of textual variants and their reoccurrence demystify the idea of a stable transmission of an unaltered text and instead presents the texts as loose amalgamations - still rigorously structured and clearly formed, at times - inviting the reader to delve into them. In short, the editorial principles of the critical edition line up closely and productively with the theory of memory in the collection, specifically with the definition of the relationship which we entertain with our past and of the strategies to recover that past in our present.

More can also be said about the consistency between Benjamin's theory of writing and the editorial principles of the critical edition of Berlin Childhood. Instead of relegating to an apparatus the textual variants which Benjamin produced during almost an entire decade, the critical edition displays in the main text all its emendations and insertions, using symbols, changing fonts, and adding marginalia in order to replicate the visual appearance of the original document. Through these visual disruptions of the reader's gaze, attention is drawn to the materiality of language as an obstacle, suggesting that reading is not a straightforward process of semantic extraction of meaning from a text. This is precisely what Benjamin presents as the heart of his theory of language, in Berlin Childhood. For a child, it is above all the graphic and phonetic appearance of words that matters, not necessarily to the exclusion of meaning, but as a diverging, alternative access to language. In one episode recounted by the narrator, for instance, the child encounters potboilers in his school's library and loses himself in the "Gestöber der Lettern" [flurry of letters] (1: 514). This flurry of letters offers the child - and by extension the reader - the opportunity to envelop themselves in words: "Beizeiten lernte ich es, in die Worte, die eigentlich Wolken waren, mich zu mummen" [In good time, I learned how to wrap myself into the words that were actually clouds] (1: 538). Words become nebulous, enveloping clouds: it is this unsettling of the text, brought out by the editorial principles of the critical edition, that forecloses the text from being read as a 
charming, nostalgic reminiscence which merely entertains or delights the reader with its style. Instead, the reader is forced to engage with Benjamin's theory of language through the very encounter with Benjamin's own language.

The importance attributed to the materiality of Benjamin's writing reaches a highpoint in one of the most impressive aspects of the editorial project published by Suhrkamp: the accompanying online digital database Walter Benjamin Digital (2016-). This resource is set to pair the publication of volumes 17, 18, and 20 as well - that is, the volumes gathering the unfinished late works - and the advantages which it offers partially counterweight the almost prohibitive retail price of the printed volumes. The range of features of the online digital database combines practicality with the possibility to wrap oneself into the text as if it were a nebulous cloud: the manuscripts are displayed as digital facsimiles overlaid with diplomatic transcriptions which can be smoothly crossfaded. A search tool allows us to trace individual words or sentences and to arrange the texts according to their edition, their repository, or the project to which they belong. The search tool is supplemented by bookmark and download tools as well as by a trilingual (German, English, French) description. While there certainly exists the danger of a fetishization of the "original" text in the form of the facsimile, this online resource is not only extremely useful to the reader, but also helps to counteract the occasional resurfacing of hagiographic reverence in Benjamin studies by presenting texts as mobile creations which exist to be rummaged through, dug up, and disseminated.

\section{Bibliography}

Hamburger Stiftung zur Förderung von Wissenschaft und Kultur, 2016-. Walter Benjamin Digital. Available from: https://www.walter-benjamin.online/ (Accessed: 2021-06-24). 